\title{
EPIDEMIOLOGY OF PUERPERAL FEVER: THE CONTRIBUTIONS OF ALEXANDER GORDON
}

by

\author{
GEORGE W. LOWIS *
}

The historical controversy regarding priority in the discovery of the contagiousness of puerperal fever ${ }^{1}$ persists, most medical historians ascribing it to two nineteenth-century physicians: the American Oliver Wendell Holmes (1809-1894) ${ }^{2}$ and/or the Hungarian Ignaz Semmelweis (1818-1865). ${ }^{3}$ That conclusion, however, is not borne out by this study.

It is true that Holmes was the first American physician to call puerperal fever a contagion - spread by doctors in private practice-and forcefully and publicly to declare that "doctors were instruments of death" unless they cleaned their hands and clothes to

* George W. Lowis, PhD, Department of Epidemiology and Public Health, School of Medicine, University of Miami, Florida, USA.

The author wishes to express deep appreciation to Mr Alexander Adams, Librarian of the Medico-Chirurgical Society of Aberdeen, for first suggesting this topic and lending his enthusiastic support.

\footnotetext{
' For an excellent overview of contagion theory and the nature of this disease, see Gail P. Parsons, 'The British medical profession and contagion theory: puerperal fever as a case study, 1830-1860', Med. Hist., 1978, 22 : 138-50; Roderick E. McGrew, 'Puerperal fever', in Roderick E. McGrew, Encyclopedia of medical history, London, Macmillan, 1985, pp. 291-4; Samuel Kneeland, 'On the contagiousness of puerperal fever', Am. J. Med. Sci., 1846, 11: 45-63.

Puerperal fever is a highly contagious, usually fatal, haemolytic streptococcus infection which attacks the uterus in postpartum women. The raw open wound of placental separation, combined with the trauma of delivery, creates an excellent breeding ground for the introduction of infected bacterial matter into the blood stream. In the absence of sterile procedures, most infectious bacteria enter from the outside via the medical agent $s$ (physician, nurse or midwife) hand, clothes, or instruments, or the medical agent brings this bacteria from another patient 's wound, abscess or autopsy matter. Occasionally, however, the genitalia's own bacteria may be harmful. Even today, because the organism responsible for streptococcal infection is ubiquitous, designation of the source of infection, i.e., where the infective agent is housed, is difficult. Genital tract infection can result in a variety of diseases including, for example, peritonitis, lymphangitis, or pyaemia. Epidemic puerperal fever did not appear until the mid-seventeenth century, and became most prevalent with the expansion of hospital facilities and the rich infective environment of the hospital wards including the insanitary habits of the physicians, barber-surgeons and midwives.

2 For a sympathetic evaluation of Holmes see Charles J. Cullingworth, Oliver Wendell Holmes and the contagiousness of puerperal fever, London, Henry J. Glaisher, 1906, pp. 1-8. Dr Cullingworth delivered an address on 28 Oct. 1905 to the Trowbridge division of the British Medical Association to honour Holmes"s work on puerperal fever, particularly his thesis on the contagiousness of this disease, and to offer evidence that Holmes, and not Semmelweis, should receive credit for having first proposed the contagious nature of this disease. See also J. B. Litoff, American midwives: 1860 to the present, Westport, Conn., Greenwood Press, 1978, p. 19; J. Leavitt, Brought to bed: childbearing in America, 1750 to 1950, New York, Oxford University Press, 1986, p. 155; R. W. Wertz and D. C. Wertz, Lying-in: a history of childbirth in America, New Haven, Yale University Press, 1989, pp. $120-3$.

${ }^{3}$ A thoroughly competent summary of the puerperal fever theories of Semmelweis, Holmes and Gordon-but with a favourable inclination toward Semmelweis-appears in W. J. Sinclair, Semmelweis, his life and doctrine, a chapter in the history of medicine, Manchester University Press, 1909. See also K. Codell Carter, 'Semmelweis and his predecessors', Med. Hist., 1981, 25: 57-72; Ernst L. Wynder, 'Ignaz Philipp Semmelweis', Prev'. Med., 1974, 3: 574-80; Leavitt, op. cit., note 2 above, pp. 155, 184; Litoff, op. cit., note 2 above, p. 19; Wertz and Wertz, op. cit., note 2 above, p. 121; McGrew, op. cit., note 1 above, pp. 293-4.
} 
prevent this transportation. ${ }^{4}$ It is also true that Semmelweis-although denying that puerperal fever was contagious ${ }^{5}$ - was the first to demonstrate the contagiousness of this fever statistically. ${ }^{6}$ He showed that there was a much higher mortality in the hospital wards open to medical students and physicians than in those to which only midwives were admitted; and that the infective material that conveyed the fever was brought by the students and physicians who had attended the dead bodies in the post-mortem room. His solution was to insist on certain antiseptic preventive means such as requiring that all birth attendants wash their hands in a chloride of lime solution before attending childbirths. ${ }^{7}$ This was one of the earliest applications of antisepsis, the first probably having occurred some time before 1843 in Boston. ${ }^{8}$

A careful review, however, of the medical literature reveals that it was Alexander Gordon (1752-1799), ${ }^{9}$ a Scottish physician, who-approximately forty years before Holmes and Semmelweis-clearly and systematically demonstrated the contagious and transmissible nature of this disease by showing that puerperal sepsis spread from the medical agent (nurse, doctor or midwife) to the patient and/or from patient to patient by way of the hands of the attending medical agent. ${ }^{10}$ Aetiology was established in his meticulous epidemiological study of puerperal fever ${ }^{11}$ conducted in and around the city of Aberdeen in the early 1790s.

\footnotetext{
${ }^{4}$ See especially Oliver Wendell Holmes, 'The contagiousness of puerperal fever', N. Engl. J. Med. Surg., 1843, and reprinted in Oliver Wendell Holmes, Medical essays, Boston, Houghton Mifflin, 1891, pp. 103-72; Ralph H. Major, A history of medicine, vol. 2, Oxford, Blackwell Scientific Publications, 1954, pp. 756-9; Charles Singer, $A$ short history of medicine, Oxford, Clarendon Press, 1928, p. 243; Wertz and Wertz, op. cit., note 2 above, pp. 120-3.

${ }^{5}$ Contagion, for Semmelweis, consisted of the direct spread of a disease from patient to patient but this was not the way puerperal fever spread. That he was committed to "anticontagionism" is a proposition emphasized by only a handful of writers such as Parsons, op. cit., note 1 above, p. 145; Cecelia C. Mettler, History of medicine, Philadelphia, Blakiston, 1947, p. 965; Edwin H. Ackerknecht, 'Anticontagionism between 1821 and 1867', Bull. Hist. Med., 1948, 22: 562-93; Tiberius Gyory, 'Oliver Wendell Holmes and Semmelweis', Br. Med. J., 1906, ii: 715-16.

${ }^{6}$ Wynder, op. cit., note 3 above, pp. 575-8.

${ }^{7}$ See Douglas Guthrie, A history of medicine, London, Thomas Nelson, 1945, pp. 318-20; Singer, op. cit., note 4 above, p. 243; Major, op. cit., note 4 above, pp. 785-7; Parsons, op. cit., note 1 above, p. 145; Carter, op. cit., note 3 above, p. 57; Wertz and Wertz, op. cit., note 2 above, p. 121.

${ }^{8}$ Holmes describes what was probably the first application of antisepsis: a Boston physician attending a female patient with fever changed his clothing and washed his hands in a solution of lime after each visit. See Holmes, op. cit., note 4 above, pp. 149-52.

${ }^{9}$ Important biographical data are found in Ian A. Porter, Alexander Gordon, M.D., of Aberdeen, 1752-1799, Edinburgh, Oliver and Boyd, 1958, pp. 3-54. See also Herbert Thoms, 'Gordon of Aberdeen', Am. J. Obstet. Gynecol., Feb. 1928, 15: 229-33, pp. 230-1.

${ }^{10}$ The basic point of this paper, that Gordon, and not Semmelweis or Holmes, should be credited with having first demonstrated the contagious and transmissible nature of puerperal fever, is emphasized in the recently published book by Irvine Loudon, Death in childbirth, New York and London, Oxford University Press, 1992, see especially his chapter 4. See also A. W. W. Lea, Puerperal infection, London, Henry Frowde, Hodder \& Stoughton, 1910; Robert J. Lee, The Goulstonian lectures on puerperal fever, London, Smith, Elder, 1875, pp. 19-33; C. G. Drummond and H. P. Tait, 'The history of midwifery in eighteenth, nineteenth, and early twentieth-century Aberdeen', Med. Hist., 1978, 22: 205-6; L. Colebrook, 'The story of puerperal fever, 1800-1950', Br. Med. J., 1956, i: 247; Thoms, op. cit., note 9 above, pp. 229-233; Porter, op. cit., note 9 above, pp. v.vII. 64-77. The nineteenth-century data offered by both Holmes and Semmelweis show that unsanitary conditions prevailed in American and British hospitals, which were rarely free of septic disease; they show also that medical agents played a dominant role in the transmission of puerperal fever. It is interesting to note that the latter finding constituted one of Gordon's most important findings in the previous century, and was obviously readily available in the medical literature, yet only Holmes publicly recognized Gordon's contributions.

"'Several writers have described Gordon's essay as the first epidemiological study of puerperal fever. See, for example, McGrew, op. cit., note 1 above, p. 292; Wertz and Wertz, op. cit., note 2 above, p. 120.
} 


\section{Epidemiology of puerperal fever}

His findings, which present the most comprehensive eighteenth-century epidemiological data on this disease, were initially published in $1795,{ }^{12}$ and were published again as reprints in 1822,1842 and $1849 .^{13}$

Alexander Gordon was born in 1752 in the small parish of Peterculter, Aberdeenshire, about twenty miles south-west of the city of Aberdeen, Scotland, and died at his brother's home in Logie, Aberdeenshire, forty-seven years later of pulmonary tuberculosis. Gordon had two daughters, Mary and Elizabeth, by his wife Elizabeth Harvie, whom he married in 1784, only one of whom (Mary) survived, and later married a former pupil of his, Robert Harvey of Braco. He attended Marischal College in Aberdeen from 1771 to 1775, where he took his MA degree before pursuing a medical career. Although medical subjects had been included in the curriculum of Marischal from the time of its founding in 1593, it did not have a medical school where a degree-granting course of instruction could be pursued. Gordon, therefore, formally embarked on a study of medicine by receiving clinical instruction at the Aberdeen Infirmary, which had been opened in 1742 . He continued his medical studies at the medical schools of Edinburgh (Scotland) and Leiden (Holland), spent five years of naval service on various ships of His Majesty's Navy as first a surgeon's mate and later as a surgeon (1780-1785); and upon retirement from the Navy went to London to study and receive instruction in midwifery from some of the most eminent obstetricians of the day.

At the end of 1785, Gordon left London for Aberdeen, where he was appointed physician to the Aberdeen Dispensary, which had begun its clinical work in 1781, with which he was to remain intimately connected during his entire professional life in Aberdeen. As dispensary physician, he attended to patients with a variety of diseases and illnesses, including, for example, measles, rheumatism, erysipelas and inflammatory sore throat. He also offered classes in midwifery to medical students and midwives. No doubt because of his impressive formal education and extensive medical training and expertise, and also probably on recommendation of eminent doctors with whom he had worked, Gordon was awarded the MD degree from Marischal College in 1788.

At the time when the epidemic of puerperal fever began in Aberdeen, ${ }^{14}$ he was probably the only trained obstetrician in the city, and therefore the entire burden of the epidemic fell on him. He was, however, sufficiently knowledgeable in the fundamentals of medicine to be able to make observations which later proved to be epidemiologically important.

After the 1795 publication of his treatise on puerperal fever, he returned to the Navy as naval surgeon, never again to practise obstetrics and midwifery. Apparently the populace of

\footnotetext{
${ }^{12}$ Alexander Gordon, A treatise on the epidemic puerperal fever of Aberdeen, London, G. G. and J. Robinson, 1795. The original manuscript is located in the rare book section of the University of Aberdeen library. The treatise consists of seven chapters, which reveal the comprehensive epidemiological nature of the subject matter Gordon dealt with: (1) a history and symptoms of the disease; (2) cases and dissections of the disease; (3) nature and seat of the disease; (4) course of the disease; (5) prognosis of the disease; (6) cure of the disease; and, (7) prevention of the disease.

${ }^{1.3}$ William Campbell, A treatise on the epidemic puerperal fever as it prevailed in Edinburgh, I821-1822, Edinburgh, Bell \& Bradfute, 1822; E. Barrington and G. D. Haswell, The history, pathology, and treatment of puerperal fever and crural phlebitis, essays by Drs Alexander Gordon, William Hey, John Armstrong and Robert Lee, Philadelphia, 1842; Fleetwood Churchill (ed.), Essays on the puerperal fever and other diseases peculiar to women, London, The Sydenham Society, 1849. This anthology contains essays written entirely by eighteenthcentury physicians and obstetricians.

${ }^{14}$ Gordon, op. cit, note 12 above, chapter 1. Gordon's treatise contains the results of his observations on an outbreak of puerperal fever in Aberdeen which made its appearance in December, 1789 and prevailed until March, 1792; he allowed between two and three years to elapse before he wrote up his findings.
} 
Aberdeen, together with the midwives, believed that Gordon was himself responsible for the whole epidemic and were instrumental in making life very difficult for him. The midwives, especially, must have been angry, as they had strongly disapproved of his treatment of the postpartum patients (by bloodletting and purging), and had been

Table 1

Containing an account of those patients affected with the puerperal fever, who were attended by $\mathrm{Dr}$ Gordon from December 1789, to October 1792.

\begin{tabular}{llll}
\hline $\begin{array}{l}\text { When } \\
\text { taken } \\
\text { ill No. Name }\end{array}$ & & $\begin{array}{l}\text { By } \\
\text { whom } \\
\text { delivered }\end{array}$ \\
\hline
\end{tabular}

\section{9}

Dec. 1 Jas. Garrow's wife

Do. 2 Jas. Smith's wife

Do. 3 John Smith's wife

Do. 4 Al. Mennies wife 1790

Jan. 5 J. Anthony's wife 25

Feb. 6 Christian Durward 36

Apr. 7 Al. Stuart's wife 30

May 8 Wm. Elrick's wife 34

Do. 9 Elizabeth Murray 28

Do. 10 Helen Mitchell

Do. 11 Janet Wier

Aug. 12 Mrs Johnston

Do. 13 Geo. Webster's wife

Do. 14 Peter Paul's wife

Do. 15 John Low's wife

Do. 16 Mrs Milne

Sep. 17 Isabel Allan

Do. 18 Robt. Burr's wife

Oct. 19 Al. Eddy's wife

Do. 20 Agnes Milne

Do. 21

Do. 22

Do. 23

Do. 24

Do. 25

Do. 26

Do. 27

Do. 28

Nov. 29

Do. 30

Do. 31

Do. 32

Do. 33

Do. 34

Dec. 35

Do. 36

Do. 37

Do. 38
Al. Stuart's wife

Eliza'th Jamieson

D. Nicol's wife

Al. Brown's wife

Anne Smith

Mrs Malcom

W. Robertson's wife

Jean Webster

Anne Cumming

Margaret Still

Janet M'Kay

Jean Laing

Mrs Leitch

Anne Barclay

Mrs Muffart

Jean Galloway

Janet Anderson

Mrs
30

34

25

28

30
34

36

38

32

25

27

36

30

36

24

26

25

25

27

24

25

30

\section{7}

\section{9}

25

38

32

\section{0}

\section{0}

\section{6}

27

25

25
Woolman-hill

Do.

Green

Hardgate

North-street

Rottenholes

Denburn

Exchequer-wynd

North-street

Do.

Denburn

Littlejohn's s-str't

Fowler's-wynd

Windmill-brae

Justice-mills

North-street

Birnie's-close

Gallowgate

Do.

Putachie-side

Green

Windmill-brae

Green

Loan-head

Denburn

Green

Gilcomston

Justice-port

North-street

Do.

Gallowgate

Do.

Carnegie's-brae

Tannery-street

Hardgate

North-street

Putachie-side 5th day Mrs Blake

23rd Do.

11th Mrs Elgin

11th Do.

3rd Dr Gordon

3rd Do.

Mrs Philp

Mrs Blake

7th Do.

Do.

Mrs Elgin

5th Mrs Smith

Mrs Blake

Do.

5th Mrs Smith

Mrs Blake

5th Mrs Coutts

2nd Mrs Irvine

3rd Mrs Clark

Do.

Mrs Blake

5th Dr Gordon

Mrs Philp

5th Mrs Elgin

5th Do.

1st Do.

5th Mrs Emslie

Mrs Anderson

Do.

Do.

Mrs Clark

7th Dr Gordon

Do.

Mrs Clark

Mrs Davidson

Mrs Anderson

5th Mr Harvey

5th Dr Gordon 
individually named in his study as persons who had delivered particular patients and were indeed responsible for carrying the disease to their patients. Gordon's bloodletting procedures must have been especially crucial in creating this hostile community atmosphere. But mainly as a consequence of his clinical experience in London with this

\begin{tabular}{|c|c|c|c|c|c|c|c|}
\hline $\begin{array}{l}\text { When } \\
\text { taken } \\
\text { ill }\end{array}$ & No. & Name & Age & Residence & Cured. & Dead & $\begin{array}{l}\text { By } \\
\text { whom } \\
\text { delivered }\end{array}$ \\
\hline \multicolumn{8}{|l|}{1791} \\
\hline Jan. & 39 & A. Main's wife & 40 & Poinernook & & 1st & Mrs Henderson \\
\hline Feb. & 40 & Violet Thom & 25 & Green & 20 & & Dr Gordon \\
\hline Do. & 41 & Mrs Home & 22 & Carnegie's-brae & 21 & & Mrs Ogilvie \\
\hline Do. & 42 & Mrs Walton & 25 & North-street & & 11 th & Do. \\
\hline Do. & 43 & Elspet Riach & 25 & Do. & & 5th & Mrs Balfour \\
\hline Mar. & 44 & Janet Cormack & 25 & Back-wynd & 22 & & Do. \\
\hline Mar. & 45 & And. Duncan's wife & 26 & Back-wynd & & 5th day & Mrs Blake \\
\hline Do. & 46 & Anne Davidson & 34 & Justice-port & 23 & & Mrs Anderson \\
\hline Do. & 47 & Elspet Fife & 30 & Windmill-brae & 24 & & Mrs Keith \\
\hline Do. & 48 & Margaret Forbes & 40 & Footdee & 25 & & Mrs Anderson \\
\hline Apr. & 49 & Janet Robertson & 36 & Correction-wynd & 26 & & Mrs Coutts \\
\hline Do. & 50 & Wm. Gibbon's wife & 27 & Do. & 27 & & Dr Gordon \\
\hline Do. & 51 & John Duncan's wife & 26 & Woman-hill & & 7th & Mrs Keith \\
\hline Do. & 52 & J. Davidson's wife & 25 & Castle-street & 28 & & Dr Gordon \\
\hline Do. & 53 & Rachel Gordon & 36 & Do. & 29 & & Mrs Mitchell \\
\hline May & 54 & Mrs Clark & 25 & Gallowgate & 30 & & Dr Gordon \\
\hline Do. & 55 & Geo. Duthie's wife & 30 & Torry & & 5th & Mrs Philp \\
\hline June & 56 & Anne Molison & 27 & Windmill-brae & 31 & & Mrs Emslie \\
\hline Do. & 57 & Mrs Henrie & 30 & Lodge-walk & 32 & & Mrs Elgin \\
\hline Sep. & 58 & Elspet Robertson & 25 & Shoe-lane & 33 & & Mrs Blake \\
\hline Do. & 59 & Rachel Leith & 25 & Back-wynd & 34 & & Mrs Taylor \\
\hline Do. & 60 & Mrs Thomson & 25 & Lodge-walk & 35 & & Dr Gordon \\
\hline Oct. & 61 & Mrs Ligertwood & 30 & Queen-street & 36 & & Do. \\
\hline Do. & 62 & Widow Forbes & & Printfield & 37 & & Mrs Taylor \\
\hline Nov. & 63 & Mrs Brown & 42 & Fintray & & 5th & Mrs Mitchell \\
\hline Do. & 64 & Mary Meldrum & 32 & Windmill-brae & & 5th & Mrs Chalmers \\
\hline Dec. & 65 & Jean Brown & 36 & Vennel & 38 & & Mrs Anderson \\
\hline Do. & 66 & Margaret Yull & 23 & Castle-street & 39 & & Dr Gordon \\
\hline Do. & 67 & Anne Hervie & 23 & Woman-hill & 40 & & Mrs Keith \\
\hline $\begin{array}{l}\text { Do. } \\
\text { I792 }\end{array}$ & 68 & Isaac Allan's wife & 22 & Windmill-brae & 41 & & Mrs Emslie \\
\hline Jan. & 69 & Mrs White & 30 & Printfield & & 5th & Mrs Keith \\
\hline Do. & 70 & Mrs Byrn & 27 & Broadgate & 42 & & Mrs Philp \\
\hline Do. & 71 & Christian Sangster & 30 & Green & 43 & & Mrs Ogilvie \\
\hline Feb. & 72 & Al. Sim's wife & 27 & Printfield & 44 & & Mrs Chalmers \\
\hline Do. & 73 & Jas. Gordon's wife & 28 & Do. & 45 & & Dr Gordon \\
\hline Do. & 74 & Mrs Mather, & 26 & Drum & 46 & & \\
\hline Mar. & 75 & T. Wallader's wife & 36 & Printfield & 47 & & Mrs Keith \\
\hline Do. & 76 & Mrs Imlach & 24 & Pesly & 48 & & Dr Gordon \\
\hline Oct. & 77 & Anne Skinner & 36 & Gallowgate & 49 & & Do. 2 \\
\hline
\end{tabular}


disease, he was convinced that copious bleeding was a certain cure, while the rest of the community believed the epidemic to be an ephemeral fever called the "Weed" and denied the relevance of bloodletting as a cure.

Gordon's discovery of the infective nature of puerperal fever cannot be adequately understood unless we assess its relationship to the contributions made by other medical researchers. Although a clinical picture of the disease is first found in the Hippocratic Epidemics, Books I and III, ${ }^{15}$ the best early work was done by eighteenth-century English medical men. ${ }^{16}$ The earliest suggestions that puerperal fever might be infectious were offered by John Burton in 1751 and John Leake in 1752. ${ }^{17}$ Since twelve epidemics of puerperal fever occurred in Scotland and England during 1760-1788, it is not surprising that many authors writing during this period supported a medical view that puerperal fever was an infectious disease, a disease, however, they believed to originate in the atmosphere. ${ }^{18}$ We now know, of course, that although their aetiological assumption regarding the infectious nature of puerperal fever was correct, it was based on a wholly erroneous atmospheric conception of the nature of its transmission. Two of Gordon's contemporaries, however, Joseph Clarke and Charles White came very near to the truth when they offered a number of intuitive observations regarding aetiology, transmission and prevention. Writing in 1790 , Clarke disagreed with the prevailing theory that something noxious in the atmosphere played an important role in disease transmission, and argued instead that this fever had its origin in some local contagion. This conclusion was based on his observation that, in the Dublin hospital with which he was affiliated, puerperal fever deaths had occurred in only three out of four wards, not a single patient having died of this disease in one ward. ${ }^{19}$ His recommendation was to isolate all infected patients, wash all bedding and thoroughly clean hospital walls and ceilings. On the other hand, as early as 1773 , White had suggested the necessity of initiating prophylactic regimens to combat the fever. Specifically, to prevent this disease an adequate supply of fresh air and clean surroundings for the female patient were required. ${ }^{20}$ This suggestion, however, did not specify that special measures should be instituted to ensure the cleanliness of the medical and nursing attendants - thereby demonstrating that his prophylactic measures were based on an erroneous conception of how this disease was transmitted. ${ }^{21}$

\footnotetext{
15 John Chadwick and W. N. Marın (transl.) The medical works of Hippocrates, Oxford, Blackwell Scientific Publications, 1950, 'Epidemics, Book I', pp. 46-8, 51-2 and 'Book III', pp. 70-1, 78-9. See also Roderick E. McGrew, 'Epidemiology', in Roderick E. McGrew, op. cit., note 1 above, p. 108; McGrew, op. cit., note 1 above, p. 291.

${ }^{16}$ Original essays on puerperal fever by physicians and obstetricians who preceded Gordon in research of this disease include Nathaniel Hulnıe, Charles White, John Leake, William Butter, Joseph and John Clarke, Thomas Denman and Thomas Kirkland, and are found in Churchill, op. cit., note 13 above, pp. 43-116, $205-443$. Excellent summaries, also, of the research of Joseph Clarke, Charles White, and others appear in Porter, op. cit., note 9 above, pp. 57-63, 78-82.

${ }^{17}$ Porter, ibid., p. 78.

ix Ibid., pp. 78-9.

19) Ibid., pp. 61-2, 79; Churchill, op. cit., note 13 above, pp. 351-62.

20) Charles White, A treatise on the management of pregnant and lying-in women, London, 1773. See also Churchill, op. cit., note 13 above, pp. 205-80; Wertz and Wertz, op. cit., note 2 above, p. 120; Guthrie, op. cit., note 7 above, p. 318; McGrew, op. cit., note 1 above, pp. 291-2.

${ }^{21}$ Porter, op. cit., note 9 above, pp. 81-2.
} 


\section{Epidemiology of puerperal fever}

In the remainder of this paper, an examination of Gordon's treatise ${ }^{22}$ will be undertaken with the purpose of establishing how successful he was in offering a comprehensive systematic epidemiological view of puerperal fever. My principal focus will be on the three epidemiological themes that dominate his study, aetiology, method of treatment and prevention, which I shall describe as far as possible in the author's own words.

\section{AETIOLOGY}

Two related problems were addressed by Gordon here: the infectious and transmissible nature of puerperal fever. Although many eighteenth-century medical researchers accepted an infectious explanation for this disease, they incorrectly theorized that there was a connection with a noxious constitution of the atmosphere. Gordon's observation, however, that women infected with the fever had been delivered at the same time as others who did not develop this disease, and in the same atmosphere, suggested that another explanation was required. ${ }^{23}$ The explanation that he eventually offered, and a key finding relevant to the knowledge of puerperal fever prevailing at that time, concerned the unique manner in which this infection was transmitted.

It was possible for Gordon to demonstrate the infectious and transmissible nature of this disease through observation. Whereas many other eighteenth-century researchers were disposed to use reason and theory without recourse to facts, Gordon's approach was dominated by the actual observation of patients - either the cases he dissected or saw in his capacity as physician.

There have been subjects of great dispute among writers on the puerperal fever. And I hope, that the observations which an extensive experience has enabled me to make will serve to illustrate the points in dispute ... I am fully persuaded, that if practitioners had observed more and reasoned less, there would have been little dispute, either about the nature or seat of this disease. ${ }^{24}$

Using observational data, which comprised a detailed description of seven cases of the disease with the post-mortem findings in three fatal cases, ${ }^{25}$ together with a table he constructed of all the patients under his care who were stricken with the fever during the epidemic, ${ }^{26}$ Gordon demonstrated empirically that the cause of puerperal fever was a "specific contagion or infection" transmitted from one patient to another by a third party or medical agent (midwife, nurse, or himself). ${ }^{27}$ The aforementioned table of cases was the material on which Gordon principally based his findings concerning the infectious and transmissible nature of this disease. Gordon's observation that puerperal fever was

\footnotetext{
22 During my visit to the University of Aberdeen library in the summer of 1992, Gordon's original (1795) essay was not available for inspection; so a copy of the 1842 anthology by Barrington and Haswell, op. cit., note 13 above, was obtained. It contains a comprehensive reproduction of the Gordon study in its entirety; all subsequent references are thus to the full reprint in the 1842 anthology.

${ }^{2.3}$ Porter, op. cit., note 9 above, p. 79.

24 Barrington and Haswell, op. cit., note 13 above, p. 46.

${ }^{25}$ Ibid., pp. 35-46. The total number of patients under Gordon's care during the epidemic was 77. From this total, he selected 7 cases as typical to illustrate primarily, and in great detail, some of the more important epidemiological characteristics of this disease including, for example, aetiology, diagnosis, dissection, treatment, prevention and prognosis.

${ }^{26}$ Ibid., pp. 36-7. See Table 1.

${ }^{27}$ Ibid., pp. 50-1.
} 
infectious and that the infection could be carried from one patient to another through one or more medical agents was illustrated by reference to the tables of cases:

The midwife who delivered No. 1 in the table carried the infection to No. 2, the next woman whom she delivered. The physician who attended Nos. 1 and 2, carried the infection to Nos. 5 and 6 , who were delivered by him, and to many others. The midwife who delivered No. 3 , carried the infection to No. 4; from No. 24 to Nos. 25, 26, and successively, to every woman whom she delivered. The same thing is true of many others, too tedious to be enumerated. $^{28}$

That Gordon had clearly and unequivocally identified the contagiousness of this disease, and saw how the infection was carried from patient to patient by midwives or by himself, is further revealed in these remarks:

Now it may seem remarkable that the puerperal fever should prevail in the new town and not in the old town of Aberdeen, which is only a mile distant from the former . . . But the mystery is explained, when I inform the reader that the midwife, Mrs Jeffries, who had all the practice of that town, was so very fortunate as not to fall in with the infection; otherwise the women whom she delivered would have shared the fate of others. ${ }^{29}$

Continuing to emphasize the channel by which this disease was spread, Gordon offers this observation:

What the cause was, shall be mentioned afterwards, in its proper place. For the present I shall only remark that, by observation, I plainly perceived the channel by which it is propagated; and I arrived at the certainty in the matter, that I could venture to foretell what women would be affected with the disease, upon hearing by what midwife they were to be delivered or by what nurse they were to be attended during their lying-in; and almost in every instance my prediction was verified. ${ }^{30}$

Considering the primitive character of eighteenth-century obstetric medicine, the assertion by Gordon that he could predict which female patients would be affected with puerperal fever, by knowing which medical agents treated them, was indeed a radical step forward in epidemiological thinking; inasmuch as he was referring to the researcher's ability to predict successfully the development of disease in human subjects. Most importantly, however, unlike some of his contemporaries such as Charles White who believed in multiple causes of diseases, Gordon postulated a single aetiological explanation of puerperal fever. And with candour and scientific objectivity Gordon also implicated himself as an agent of transmission in the following passage. "It is a disagreeable declaration for me to mention, that I myself was the means of carrying the infection to a great number of women." 31

To Gordon, the data exhibited in the foregoing table showed that this disease could not be correlated with any particular characteristics of patients since cases tended to be distributed equally in the city of Aberdeen and adjacent countryside, among the strong and weak, robust and delicate, young and old, married and single, and among the lower and

\footnotetext{
${ }^{28}$ Ibid., p. 51.

29 Ibid., p. 51.

30 Ibid., p. 31.

${ }^{31}$ Ibid., p. 51.
} 


\section{Epidemiology of puerperal fever}

higher social classes. ${ }^{32}$ Nor could the disease be correlated with a noxious atmosphere. He dismissed this latter conception thus:

But that the cause of the epidemic puerperal fever... was not owing to a noxious constitution of the atmosphere, I had sufficient evidence; for, if it had been owing to that cause, it would have seized women in a more promiscuous and indiscriminate manner. But this disease seized such women only as were visited, or delivered, by a practitioner, or taken care of by a nurse who had previously attended patients affected with the disease. ${ }^{33}$

One can only speculate as to why Gordon did not receive credit and acknowledgement by medical historians for having been the first to establish successfully the aetiological basis for puerperal fever. Perhaps, however, one explanation may be related to Gordon's statements on the transmissibility of this infection. Gordon did, of course, effectively demonstrate by what channel puerperal fever was transmitted, i.e., how the infection travelled from patient to patient by way of the hands of midwives or of himself. He also, however, admitted to an important limitation, namely that he was unable to discover what the physical qualities of the infection were. ${ }^{34}$ At least one critic, while giving Gordon credit for having been one of the first researchers to be aware of transmissibility and contagiousness, criticizes him for failing to identify the "poison" that was causing the disease. ${ }^{35}$ If medical historians have also used this shortcoming as a basis for overlooking Gordon as the most important figure in the discovery of the aetiology of puerperal fever, then it is certainly reasonable to ask why Holmes and Semmelweis were not also denied such recognition since neither was able to identify what the nature of the "poison" was that was causing illness and death. It was, of course, not until the late nineteenth century that physicians began to realize that the bacteriological discoveries of Louis Pasteur, Robert Koch, and Joseph Lister could be applied to the practice of obstetrics.

\section{TREATMENT}

During the eighteenth century, differences of opinion regarding puerperal fever revolved around the question of whether this disease was to be considered inflammatory or putrid. Physicians regarded this as important because how the disease was to be treated, or what cure was introduced, depended on the nature of the condition. An inflammatory disease, for example, was treated differently from a putrid disease. ${ }^{36}$

Gordon regarded puerperal fever as an inflammatory disease, at least in its initial stages. After the disease had commenced, his method of treatment was to bleed or purge the patient as early as possible because if the disease were allowed to progress untreated it would become putrid; and once putrid, later treatment almost always resulted in the death of the patient. Gordon describes the necessity for early treatment, especially bleeding, in the following paragraphs:

\footnotetext{
32 Ibid., p. 31. Within the social classes, however, Gordon found a higher frequency among lower class women but that "women in the higher walks of life were not exempted, when they happened to be delivered by a midwife or physician who had previously attended any patients labouring under the disease."

${ }^{33}$ Ibid., p. 50.

34 Ibid, pp. 50-51.

${ }^{35}$ Cullingworth, op. cit., note 2 above, pp. 6-7.

${ }^{36}$ Porter, op. cit., note 9 above, p. 68.
} 


\section{George W. Lowis}

If the disease has been neglected, or improperly treated in the beginning, the event is for the most part fatal; for the inflammation, continuing to increase, terminates in suppuration or gangrene. At any rate, considerable extravasation takes place in the cavity of the abdomen; and the disease, which was inflammatory in the beginning, becomes putrid in its progress.

But though bleeding be the principal and most effectual of all remedies, yet its efficacy is limited to the beginning of the disease. ${ }^{37}$

He recommended specifically that within six to eight hours after the disease had appeared, the patient should be bled profusely-at least 20 to 24 ounces of blood should be taken at each bleeding-while simultaneously being given a single purgative.

That Gordon also regarded purging as an important treatment technique is revealed in these comments:

Purging, the other principal remedy for curing the puerperal fever . . . is well adapted to all the different stages or periods of the disease, and is the evacuation to which nature herself gives the preference; being the only proper critical, or salutary discharge, that takes place in the puerperal fever. ${ }^{38}$

According to Gordon, since "the source of the poison is in the cavity of the abdomen" it "cannot be corrected in any other way than by being carried out of the body", and if a spontaneous diarrhoea has not taken place, "the practitioner in imitation of nature, must pursue the same intention by giving purgatives". 39

This method of treatment proved to be comparatively successful; of the 77 patients treated, only 28 died, proof, according to Gordon, that he had been much more successful than any other practitioner. He insisted, and stated repeatedly, that he had discovered an effective method of treatment for puerperal fever; and he allowed this to overshadow his much more important contributions to our knowledge of this disease-namely his discovery of how it was transmitted and what effective measures for its prevention there were. Nevertheless, even though his treatment represented a significant advance on the medical practices of the day, we now know it is, in therapeutic terms, unsatisfactory. Porter contends, however, that even though Gordon erred in his method of treatment, this was of little account since "he showed the means by which it could be prevented". ${ }^{40}$

In discussing what the specific nature of the inflammation was, Gordon recognized that there was a connection between erysipelas and puerperal fever. The evidence that he brought forth to support this last statement is best presented in his own words.

I will not venture positively to assert, that the puerperal fever and erysipelas are precisely of the same specific nature; but that they are connected, that there is an analogy between them, and that they are concomitant epidemics, I have unquestionable proofs. For these two epidemics began in Aberdeen at the same time, and afterwards kept pace together; they both arrived at their acmé together, and they both ceased at the same time....

The analogy of the puerperal fever with erysipelas will explain why it always seizes women after and not before delivery. For, at the time, when the erysipelas was epidemic, almost every person admitted into the hospital of this place with a wound, was, soon after

${ }^{37}$ Barrington and Haswell, op. cit., note 13 above, p. 60.

${ }^{38}$ Ibid., p. 60.

${ }^{39}$ Ibid., pp. 60-1.

${ }^{40}$ Porter, op. cit., note 9 above, p. 82 . 


\section{Epidemiology of puerperal fever}

his admission, seized with erysipelas in the vicinity of the wound. The same consequence followed the operations of surgery: and the cause is obvious; for the infectious matter which produces erysipelas was, at that time, readily absorbed by the lymphatics, which were then open to receive it.

Just so with respect to the puerperal fever; women escape it till after delivery, for till that time there is no inlet open to receive the infectious matter which produces the disease. But after delivery the matter is readily and copiously admitted by the numerous patulous orifices, which are open to imbibe it, by the separation of the placenta from the uterus. ${ }^{41}$

It is, of course, to Gordon's credit that he could offer these keen observations in the eighteenth century, for it was not until the next century that the connection between erysipelas and puerperal fever became widely accepted. ${ }^{42}$ Not until the advent of bacteriology and the work of Pasteur, who turned to the causative organisms of these diseases, could final proof of their nature be established. ${ }^{43}$ As a consequence of this research, we now know that the large majority of fatal cases of puerperal fever are streptococcal in nature; and even though we cannot with retrospective certainty define the role played by streptococci in this disease in earlier periods, the extremely close link between erysipelas and puerperal fever plausibly implicates streptococci in puerperal fever infections in Gordon's day. ${ }^{44}$

\section{PREVENTION}

In the last chapter of his book, Gordon discussed how the infection of the puerperal fever could be prevented from being communicated. Again he wrote with great clarity:

Those who propose to prevent the puerperal fever must have two intentions in view. The one is, to prevent the infection from being communicated; and the other is, after the infection has been communicated, to prevent its action.

My endeavours were entirely directed to this last purpose; for the puerperal fever had prevailed for some time before I discovered that it was infectious; and after this discovery was made, I saw the danger of disclosing the fatal secret.

With respect to the most effectual means of preventing the infection from being communicated, I must speak with great uncertainty, because in this matter I have not experience for my guide. When treating of the cause, the nature, and cure of the disease, I spoke with the utmost confidence, because I had experience and facts for my guide; but here those sure guides are wanting, and therefore I speak with diffidence.

Whether the infection of the puerperal fever is capable of being destroyed by the same means as that of other fevers, I cannot affirm with certainty; but I think it very probable, and that they ought to be tried.

That fresh air and cleanliness are insufficient for the destruction of contagion, and that there is no certain antidote but fire and smoke has been demonstrated by the ingenious Dr. Lind. This excellent author has proved, that fire and smoke are the most powerful agents for annihilating infection; and, as he thinks, even the plague itself.

\footnotetext{
41 Barrington and Haswell, op. cit., note 13 above, p. 48.

42 Parsons, op. cit., note 1 above, p. 145.

${ }^{43}$ Porter, op. cit., note 9 above, p. 69.

44 For an excellent overview of the evolution of streptococci as causes of disease and the role played by streptococci in puerperal fever see Leonard G. Wilson, 'The early recognition of streptococci as causes of disease', Med. Hist., 1987, 31: 403-14. Wilson contends that by 1890, although the role played by streptococci in surgical infections was clear, in puerperal fever it remained in question, p. 414.
} 
The methods which he recommends for the purification of infected chambers, and for the fumigation of infected apparel, may be seen by perusing his ingenious papers on fevers and infection to which I refer the reader.

The same means ought to be practised for preventing the infection of the puerperal fever. The patient's apparel and bedclothes ought either to be burnt or thoroughly purified; and the nurses and physicians who have attended patients affected with puerperal fever ought carefully to wash themselves, and to get their apparel properly fumigated before it be put on again. ${ }^{45}$

Methods of disinfection in Gordon's day were designed to destroy or counteract contagion in the atmosphere, and included, for example, the burning of wood and the whitewashing of a patient's room. Gordon's recommendation, however, for the prevention of this disease follows directly from his discovery of how the disease is transmitted. In his schema, the atmosphere plays no important role in spreading this infection but patients and medical agents do. Therefore, whatever disinfection is to be carried out must centre on the clothing and bedroom apparel of patients and the clothing and personal hygiene of medical personnel. ${ }^{46}$ Gordon's views on the prevention of puerperal fever reveal that he understood clearly what the effective measures for the prevention of this infection were. Most importantly, he recognized the importance of cleanliness and sanitation, especially in regard to the contaminating transmission role played by the midwives and himself, even though the bacteriological discoveries which would confirm his observations were still one century away.

45 Barrington and Haswell, op. cit., note 13 above, p. 62.
46 Porter, op. cit., note 9 above, pp. $74-75$. 